\title{
THE ROLE OF FAST FOOD IN TRANSMITTING SOME BACTERIAL HAZARDS TO CONSUMERS
}

\author{
LUBNA MOHAMMED IBRAHIM and AZHAR MOHAMMED HASSAN \\ Animal Health Research Institute (Assiut Lab.)
}

Received: 27 March 2016; Accepted: 27 April 2016

\begin{abstract}
Thirty samples of ready to eat Kofta, beef burger and sausage sandwiches (10 from each) were collected from street vendors and another thirty samples of the same products (10 from each) were collected from different restaurants all were sourced from different areas in Assiut City and analyzed bacteriologically to assess the safety of these sandwiches. The results revealed that the mean values in the examined samples of street vended Kofta, beef burger and sausage sandwiches were $42.3 \times 10^{4}, 96.4 \times 10^{4}$ and $28.22 \times 10^{5} \mathrm{cfu} / \mathrm{g}$ for APC respectively, and they were $26.7 \times 10^{5}, 97.3 \times 10^{3}$ and $64.42 \times 10^{4} \mathrm{cfu} / \mathrm{g}$ in the examined samples of Kofta, beef burger and sausage sandwiches collected form restaurants respectively. Based on the microbiological guidelines for readyto-eat food by center for food safety, $80 \%$ and $50 \%$ of street vended and restaurant kofta sandwiches were satisfactory according to their APC, also the street vended and restaurant burger sandwiches had the same results. Meanwhile, $20 \%$ and $80 \%$ of street vended and restaurant sausage sandwiches were satisfactory according to their APC. Results of Enteroccocus count declared that the mean values were $11.9 \times 10^{5}, 15.61 \times 10^{4}$ and $22.68 \times 10^{4} \mathrm{cfu} / \mathrm{g}$ in the examined samples of street vended Kofta, beef burger and sausage sandwiches respectively, and they were respectively $63.3 \times 10^{4}, 34.03 \times 10^{4}$ and $28.63 \times 10^{4}$ in the examined samples of Kofta, beef burger and sausage sandwiches collected from restaurants. Some strains of Enterococcus spp. were isolated with different percentages, and identified as Ent. columbae, Ent. Cecroum, Ent.mundtii, Ent.Hirea and Ent. Facium. Staph.aureus could be isolated with an incidence of $10 \%, 40 \%$ and $60 \%$ from the examined sample of Kofta, beef burger and sausage street vended sandwiches respectively, and it was isolated with and incidence of $10 \%$ from kofta sandwiches collected from restaurants, while could not be isolated from beef burger and sausage sandwiches collected from restaurants. Based on the microbiological guideline for ready-to-eat food by center for food safety, all examined Kofta sandwiches, street vended sausage sandwiches and $80 \%$ of street vended burger sandwiches fell in the category satisfactory based on their limits of total staph.aureus count $(<20 \mathrm{cfu} / \mathrm{g})$. Also E.coli could be isolated with different percentages, the isolated serotypes were $\mathrm{O}_{55}: \mathrm{H}_{7}, \mathrm{O}_{26}: \mathrm{H}_{2}, \mathrm{O}_{26}: \mathrm{H}_{11}$ and $\mathrm{O}_{127}: \mathrm{H}_{4}$.
\end{abstract}

Key works: Fast food, Kofta, beef burger, Sauage, Staph.aureus, E.coli, APC.

\section{INTRODUCTION}

Fast food or ready to eat food are the food which are easy to make and can be eaten in an easy manner or can be taken away. The consumption and uses of fast foods have currently become a vital part of convenient food preparation patterns all over the world. According to the Food and Agriculture Organization, 2.5 billon people worldwide eat fast food every day (FAO, 2007).

There are many reasons why people eat away from home, these include absence from home whiles travelling, studying, whiles at work or need for a change both in terms of food type and the location, as a result many people purchase food from the streets. Such foods can transmit a wide range of diseases in a condition termed food infection, where the food

Corresponding author: Dr. LUBNA MOHAMMED IBRAHIM E-mail address: ghada02468@yahoo.com

Present address: Animal Health Research Institute (Assiut Lab.) serves as a vehicle for the transfer of the pathogen to the consumer, (Murray, 2003). The occurrence of

pathogenic microorganisms has always been attributed to several factors, which include contamination through water, soil, food processing equipments, food contact surfaces and most importantly food handlers (Kawo and Abdulmumin, 2009). The transmission of human diseases through food is a global problem, particularly in developing countries where gastrointestinal diseases are one of the most important causes of morbidity and mortality. However, food habits adopted by populations may mitigate or increase the hazards.

With the increasing pace of globalization and tourism, the safety of fast food has become one of the major concerns of public health, and a focus for governments and scientists to raise public awareness of food (FAO, 2007). 
As the effect of microorganisms on human health has been reported, the present study was performed to give information of distribution and presence of some pathogenic microorganisms in some fast foods from street vendors and different restaurants in Assiut City, that induces food poisoning and its impact on the consumer health.

\section{MATERIALS AND METHODS}

\section{Samples collection:}

Thirty samples of ready to eat Kofta, beef burger and sausage sandwiches (10 from each) were collected from street vendors and another thirty samples of the same products (10 from each) were collected from different restaurants, all were sourced from different areas in Assiut City. The samples were collected in sterile plastic bags in ice-box, according to (Chessbrough, 1984).

\section{Sample preparation:}

The samples were prepared according to the technique recommended by APHA, (2001)

\section{Microbiological analysis:}

- Determination of Aerobic plate count according to APHA, (2001).
- Enumeration of Enterococci according to Deible and Hartman, (1982).

- Enumeration of staph.aureus count according to FDA, (2001).

Isolation and identification of pathogenic bacteria:

- staph.aureus were isolated and identified according to ICMSF, (1996).

- E.coli were isolated and identified according to APHA, (1992), isolated strains were identified serologically according to Kok et al. (1996), by using rapid diagnostic E.coli antisera sets (Denka Seiken Co., Japan) for diagnosis of the enteropathogenic types.

- Isolation and identification of Salmonella spp. According to HPA, (2007).

- Members belonging to Enterobacteriaceae were isolated and identified according to Cowan and Steel, (1974).

- Enterocci were isolated and identified according to Morrison et al. (1997).

Statistical analysis:

Was preformed according to S.P.S.S (2007)

Acceptability of the examined samples for APC and Staph.aureus count

were detected according to microbiological guidelines CFS, (2014).

\section{RESULTS}

Table 1: Statistical analytical results of APC (cfu/g) of examined Kofta, beef burger and sausage sandwiches samples $(n=60)$.

\begin{tabular}{lccccc}
\hline Examined sandwich & Source & No & $\begin{array}{c}\text { Range of bacterial } \\
\text { count }(\mathrm{cfu} / \mathrm{g})\end{array}$ & Mean* $(\mathrm{cfu} / \mathrm{g})$ & Standard error \\
\hline Kofta $(\mathrm{S})$ & Street vendors & 10 & $<30-2 \times 10^{5}$ & $42.3 \times 10^{4}$ & $26.3 \times 10^{3}$ \\
\hline Kofta $(\mathrm{S})$ & Restaurants & 10 & $1 \times 10^{3}-2 \times 10^{6}$ & $26.7 \times 10^{5}$ & $96.3 \times 10^{3}$ \\
\hline Beef burger(S) & Street vendors & 10 & $1 \times 10^{2}-4 \times 10^{5}$ & $96.4 \times 10^{4}$ & $46.6 \times 10^{3}$ \\
\hline Beef burger(S) & Restaurants & 10 & $7 \times 10^{2}-3 \times 10^{5}$ & $97.3 \times 10^{3}$ & $33 \times 10^{3}$ \\
\hline Sausage $(\mathrm{S})$ & Street vendors & 10 & $2 \times 10^{3}-8 \times 10^{5}$ & $28.22 \times 10^{5}$ & $10.3 \times 10^{3}$ \\
\hline Sausage $(\mathrm{S})$ & Restaurants & 10 & $6 \times 10^{1}-5 \times 10^{5}$ & $64.42 \times 10^{4}$ & $49.3 \times 10^{3}$ \\
\hline
\end{tabular}

* No Significant difference $(\mathrm{P}>0.05)$

Table 2: Prevalence of accepted restaurants and street vended samples according to the microbiological guidelines (CFS, 2014) for APC

\begin{tabular}{cccc}
\hline Examined sandwich & Source & Satisfactory & Borderline \\
\hline Kofta $(\mathrm{S})$ & Street vendors & $8(80 \%)$ & $2(20 \%)$ \\
\hline Kofta $(\mathrm{S})$ & Restaurants & $5(50 \%)$ & $5(50 \%)$ \\
\hline Beef burger $(\mathrm{S})$ & Street vendors & $8(80 \%)$ & $2(20 \%)$ \\
\hline Beef burger $(\mathrm{S})$ & Restaurants & $5(50 \%)$ & $5(50 \%)$ \\
\hline Sausage $(\mathrm{S})$ & Street vendors & $2(20 \%)$ & $8(80 \%)$ \\
\hline Sausage $(\mathrm{S})$ & Restaurants & $8(80 \%)$ & $2(20 \%)$ \\
\hline
\end{tabular}


Table 3: Statistical analytical results of Enterococci counts of the examined Kofta, beef burger and sausage sandwiches samples $(\mathrm{n}=60)$

\begin{tabular}{cccccc}
\hline Examined sandwich & Source & No & $\begin{array}{c}\text { Range of Enterococci } \\
\text { counts }(\mathrm{cfu} / \mathrm{g})\end{array}$ & $\begin{array}{c}\text { Mean } \\
(\mathrm{cfu} / \mathrm{g})\end{array}$ & Standard error \\
\hline Kofta $(\mathrm{S})$ & Street vendors & 10 & $3 \times 10^{2}-7 \times 10^{5}$ & $11.9 \times 10^{5}$ & $29.9 \times 10^{3}$ \\
\hline Kofta $(\mathrm{S})$ & Restaurants & 10 & $<30-5 \times 10^{6}$ & $63.3 \times 10^{4}$ & $48.8 \times 10^{3}$ \\
\hline Beef burger $(\mathrm{S})$ & Street vendors & 10 & $8 \times 10^{1}-1 \times 10^{6}$ & $15.61 \times 10^{4}$ & $10.7 \times 10^{3}$ \\
\hline Beef burger $(\mathrm{S})$ & Restaurants & 10 & $1 \times 10^{2}-9 \times 10^{4}$ & $34.03 \times 10^{4}$ & $11.2 \times 10^{3}$ \\
\hline Sausage $(\mathrm{S})$ & Street vendors & 10 & $6 \times 10^{3}-5 \times 10^{4}$ & $22.68 \times 10^{4}$ & $17.6 \times 10^{3}$ \\
\hline Sausage $(\mathrm{S})$ & Restaurants & 10 & $1 \times 10^{2}-2 \times 10^{5}$ & $28.63 \times 10^{4}$ & $23.6 \times 10^{3}$ \\
\hline
\end{tabular}

*No Significant difference $(\mathrm{P}>0.05)$

Table 4: Prevalence of Enterococcus spp. strains isolated from examined samples

\begin{tabular}{|c|c|c|c|c|c|c|c|c|c|c|c|c|}
\hline \multirow{3}{*}{ Isolated strains } & \multicolumn{4}{|c|}{ Kofta sandwiches } & \multicolumn{4}{|c|}{ Burger sandwiches } & \multicolumn{4}{|c|}{ Sausage sandwiches } \\
\hline & \multicolumn{2}{|c|}{ S.V } & \multicolumn{2}{|c|}{$\mathrm{R}$} & \multicolumn{2}{|c|}{ S.V } & \multicolumn{2}{|c|}{$\mathrm{R}$} & \multicolumn{2}{|c|}{ S.V } & \multicolumn{2}{|c|}{$\mathrm{R}$} \\
\hline & No. & $\%$ & No. & $\%$ & No. & $\%$ & No. & $\%$ & No. & $\%$ & No. & $\%$ \\
\hline Ent. columbae & 5 & 50 & 4 & 40 & 9 & 90 & 8 & 80 & 7 & 70 & 6 & 60 \\
\hline Ent.cecorum & 1 & 10 & 0 & 0 & 0 & 0 & 0 & 0 & 0 & 0 & 1 & 10 \\
\hline Ent. mundtii & 2 & 20 & 4 & 40 & 0 & 0 & 0 & 0 & 2 & 20 & 0 & 0 \\
\hline Ent.Hirae & 0 & 0 & 3 & 30 & 0 & 0 & 0 & 0 & 1 & 10 & 0 & 0 \\
\hline Ent. Facium & 0 & 0 & 0 & 0 & 0 & 0 & 0 & 0 & 0 & 0 & 1 & 10 \\
\hline
\end{tabular}

Table 5: Prevalence of Staph.aureus isolated from examined Kofta, beef burger and sausage sandwiches samples.

\begin{tabular}{cccccccccccccc}
\hline & Kofta sandwiches & \multicolumn{4}{c}{ Burger sandwiches } & \multicolumn{3}{c}{ Sausage sandwiches } \\
\hline & s.v & & \multicolumn{2}{c}{ R } & \multicolumn{2}{c}{ s.v } & \multicolumn{2}{c}{ R } & s.v & & R \\
\hline No. & & $\%$ & No. & $\%$ & No. & $\%$ & No. & $\%$ & No. & $\%$ & No. & $\%$ \\
\hline 1 & 10 & 1 & 10 & 4 & 40 & 0 & 0 & 6 & 60 & 0 & 0 \\
\hline
\end{tabular}

*Highly significant difference $(\mathrm{P}<0.01)$

Table 6: Frequency distribution of Staph.aureus in street vended burger sandwiches.

\begin{tabular}{ccc}
\hline Frequency $(\mathrm{cfu} / \mathrm{g})$ & Number & $\%$ \\
\hline$<10$ & 6 & $60 \%$ \\
\hline 13 & 2 & $20 \%$ \\
\hline 30 & 2 & $20 \%$ \\
\hline
\end{tabular}

Table 7: Prevalence and serotyping of E.coli isolated from examined Kofta, beef burger and sausage sandwiches samples.

\begin{tabular}{|c|c|c|c|c|c|c|c|c|c|c|c|c|}
\hline \multirow{3}{*}{ Identified strains } & \multicolumn{4}{|c|}{ Kofta sandwiches } & \multicolumn{4}{|c|}{ Burger sandwiches } & \multicolumn{4}{|c|}{ Sausage sandwiches } \\
\hline & \multicolumn{2}{|c|}{ S.v } & \multicolumn{2}{|c|}{$\mathrm{R}$} & \multicolumn{2}{|c|}{ S.V } & \multicolumn{2}{|c|}{$\mathrm{R}$} & \multicolumn{2}{|c|}{ S.V } & \multicolumn{2}{|c|}{$\mathrm{R}$} \\
\hline & No & $\%$ & No & $\%$ & No & $\%$ & No & $\%$ & No & $\%$ & No & $\%$ \\
\hline E.coli $055: H 7$ & - & 0 & - & 0 & - & 0 & - & 0 & 1 & 10 & - & 0 \\
\hline E.coli O111:H2 & - & 0 & - & 0 & - & 0 & - & 0 & - & 0 & 1 & 10 \\
\hline E.coli O26: H11 & - & 0 & - & 0 & 1 & 10 & - & 0 & 1 & 10 & - & 0 \\
\hline E.coli O127:H4 & - & 0 & 1 & 10 & - & 0 & - & 0 & - & 0 & - & 0 \\
\hline
\end{tabular}


Table 8: Recovery rate of Enteric bacteria isolated from examined samples.

\begin{tabular}{|c|c|c|c|c|c|c|c|c|c|c|c|c|}
\hline \multirow{3}{*}{ Identified strains } & \multicolumn{4}{|c|}{ Kofta sandwiches } & \multicolumn{4}{|c|}{ Burger sandwiches } & \multicolumn{4}{|c|}{ Sausage sandwiches } \\
\hline & \multicolumn{2}{|c|}{$\begin{array}{c}\text { Street } \\
\text { vendors }\end{array}$} & \multicolumn{2}{|c|}{ Restaurants } & \multicolumn{2}{|c|}{$\begin{array}{c}\text { Street } \\
\text { vendors }\end{array}$} & \multicolumn{2}{|c|}{ Restaurants } & \multicolumn{2}{|c|}{$\begin{array}{c}\text { Street } \\
\text { vendors }\end{array}$} & \multicolumn{2}{|c|}{ Restaurants } \\
\hline & No. & $\%$ & No. & $\%$ & No. & $\%$ & No. & $\%$ & No. & $\%$ & No. & $\%$ \\
\hline Proteus mirabilis & - & 0 & - & 0 & 3 & 30 & - & 0 & - & 0 & - & 0 \\
\hline Klebsiella pneumoniae & - & 0 & 1 & 10 & - & 0 & - & 0 & 2 & 20 & - & 0 \\
\hline $\begin{array}{c}\text { Enterobacter } \\
\text { aerogenes }\end{array}$ & - & 0 & 1 & 10 & - & 0 & - & 0 & - & 0 & - & 0 \\
\hline
\end{tabular}

\section{DISCUSSION}

The chief purpose of microbiological examination sandwich are to give assurance that the sandwiches will be acceptable from the public health stand point and that the sandwiches will be of satisfactory quality. Roberts, (1990) reported that the three main routes by which microorganisms enter food are the foodstuff, food handlers and the environments, Whereas aerobic plate count indicates the level of microorganisms in a product and provides general estimate of live aerobic bacteria, indicating the quality, shelf life and post heat processing contamination Maturin and Peeler, (1998). It is evident from the results recorded in Table (1) that the mean values in the examined samples of street vended Kofta, beef burger and sausage sandwiches were $42.3 \times 10^{4}, 96.4 \times 10^{4}$ and $28.22 \times 10^{5} \mathrm{cfu} / \mathrm{g}$ for APC respectively, and they were $26.7 \times 10^{5}, 97.3 \times 10^{3}$ and $64.42 \times 10^{4} \mathrm{cfu} / \mathrm{g}$ in the examined samples of Kofta, beef burger and sausage sandwiches collected from restaurants respectively.

Although no significant differences in aerobic plate counts were found between the street vended and restaurants examined samples $(\mathrm{P}>0.05)$ the street vended samples of both beef burger and sausage sandwiches still had higher total viable bacterial count than those obtained from restaurants, while street vended samples of kofta sandwiches had lower viable bacterial count than those obtained from restaurants.

Exposure of the food to air or dust at the point of sale is likely to increase the counts of the bacteria as virtually most of the bacteria are carried in aerosols by dust and air Food and Drug Administration, (2009).

The variation in bacterial counts between different types of meat products could be attributed to difference of ingredients and steps involved in their formulation and preparation Hefnawy and youssef, (1984)
The obtained results were lower than those obtained by Ibrahim-Ghada, (2001) who found that, the mean values of APC in Kofta and beef burger sandwiches collected from different restaurants were $15.3 \times 10^{6}$ and $29.27 \times 10^{7} \mathrm{cfu} / \mathrm{g}$ respectively, while (Ibrahimhemmat et al., 2014) recorded that the mean value of APC in kofta collected from different restaurants was $1.83 \times 10^{4} \mathrm{cfu} / \mathrm{g}$, it was lower than that obtained in our results, also he recorded $8.61 \times 10^{4} \mathrm{cfu} / \mathrm{g}$ as a mean value of APC in sausage which was relatively agree with our results. However higher findings were obtained by (Fahim et al., 2015) who found that the mean values of APC were $8.51 \times 10^{5}, 3.97 \times 10^{5}$ and $1.33 \times 10^{6} \mathrm{cfu} / \mathrm{g}$ in examined samples of street vended kofta, beef burger and sausage sandwiches respectively.

Based on the microbiological guidelines for ready to eat foods (CFS, 2014), the obtained results in Table (2) showed that $80 \%$ and $50 \%$ of street vended and restaurant kofta sandwiches were satisfactory, 20\% and $50 \%$ were borderline quality according to their APC. Also the street vended and restaurant burger sandwiches had the same results. Meanwhile, 20\% and $80 \%$ of street vended and restaurant sausage sandwiches were satisfactory, $80 \%$ and $20 \%$ were borderline quality according to their APC.

Borderline results were due mainly to high APC, Khater-Dalia et al. (2013), reported that $40 \%$ and $60 \%$ of street vended and restaurant kofta sandwiches were of unsatisfactory microbiological quality, also he reported that unsatisfactory results were due mainly to high APC which may indicate that the cooking process was inadequate, or post cooking contamination had occurred, or the length of time and temperature control in storage or display facilities was inadequate to prevent bacterial growth, or that a combination of these factors was involved, while Fahim et al. (2015) reported that out of 80 examined samples of street vended meat products $6.25 \%$ were of unsatisfactory quality due to their APC.

Results in Table (3) declared that the mean values of Enterococci count were $11.9 \times 10^{5}, 15.61 \times 10^{4}$ and 
$22.68 \times 10^{4} \mathrm{cfu} / \mathrm{g}$ in the examined samples of street vended Kofta, beef burger and sausage sandwiches, respectively and they were $63.3 \times 10^{4}, 34.03 \times 10^{4}$ and $28.63 \times 10^{4}$ in the examined samples of kofta, beef burger and sausage sandwiches collected from restaurants, respectively.

Statistical analysis was performed using S.P.S.S (2007) it revealed that no significant differences in Enterococcus count were found between the street vended and restaurants examined samples $(\mathrm{P}>0.05)$, but the street vended samples of kofta sandwiches still had higher Entero ccus count than those obtained from restaurants.

Although there is a scarcity in the literature concerning prevalence and distribution of Enterococci in the products under examination, (Stiles and Holzapfel, 1997) reported that the ability of Enterococci to survive in the environment, their pronounced heat resistance and their dominance of the microbial population of heat-treated foods, implies that Enterococci can be used as indicators for fecal contamination. Moreover, Giraffa (2002) and Foulquie et al. (2006) concluded that Certain features, such as the ability to growth over a wide range of temperature, salinity and $\mathrm{pH}$ make these organisms able to multiply in several foods and even spoil them.

Table (4) showed the incidence of the isolated Enterococcus spp, where Ent.columbae was isolated from $50 \%, 90 \%$ and $70 \%$ of kofta, beef burger and Sausage Street vended sandwiches, respectively. The aforementioned organisms were isolated from $40 \%$, $80 \%$ and $60 \%$ of examined kofta, beef burger and sausage sandwiches collected from restaurants, Ent.cecroum was isolated from $10 \%$ of both street vended kofta sandwiches and sausage sandwiches collected from restaurants, Ent.mundtii was isolated from $20 \%$ and $40 \%$ of street vended kofta sandwiches and kofta, sandwiches collected from restaurants respectively, also could be isolated from $20 \%$ of street vended sausage sandwiches, Ent.Hirae was isolated from $30 \%$ of kofta sandwiches collected from restaurants and from $10 \%$ of street vended sausage sandwiches, while Ent.facium only was isolated from $10 \%$ of sausage sandwiches collected from restaurants.

Staphylococcus aureus is considered the third most important cases of food borne disease in the world (Normanno et al., 2007), the presence of this pathogen in fast food puts consumers at high risk (Syne et al., 2013).

It is evident from the results recorded in Table (5) that Staph.aureus was isolated with Prevalence rate $10 \%, 40 \%$ and $60 \%$ from examined kofta, beef burger and sausage street vended sandwiches respectively, while the organism could be isolated only from kofta sandwiches collected from restaurants with an incidence of $10 \%$, and could not be isolated from both of beef burger and sausage sandwiches collected from restaurants.

This results obvious that street vended sandwiches appeared to be the samples that recorded higher incidence of Staph.aureus than that recorded in sandwiches collected from restaurants. Statistical analysis revealed that there were highly significant difference in the incidence of isolated staph.aureus between streets vended examined samples and examined samples collected from restaurants $(\mathrm{P}<$ 0.01). In this respect Sharmila, (2011) reported that some vendors (in order to keep prices down) purchase cheap or adulterated ingredients containing unpermitted chemical additives from unauthorized suppliers which may further increase the risks associated with the food, also he reported that the serving utensils used at the vending site are often contaminated with Staphylococcus spp. which may have originated from the vendors hands.

Concerning Staph.aureus count, all examined kofta sandwiches and street vended sausage sandwiches showed count $<10 \mathrm{cfu} / \mathrm{g}$.

Based on the microbiological guidelines of ready to eat food (CFS, 2014), all these sandwiches fell in the category satisfactory based on their total Staph.aureus count while the frequency distribution of the organism in the examined street vended burger sandwiches as recorded in table (6) revealed that 6 $(60 \%)$ had count $<10 \mathrm{cfu} / \mathrm{g}$ and $2(20 \%)$ had count 13 $\mathrm{cfu} / \mathrm{g}$, so $80 \%$ of these sandwiches fell in the category satisfactory based on their total Staph.aureus count, and the same table showed that $2(20 \%)$ of these sandwiches had account $30 \mathrm{cfu} / \mathrm{g}$ so they fell in the category borderline based on their total Staph.aureus count.

Alzbeta and Lubomir (2012) reported that Staphylococci compete poorly with indigenous bacteria and are inhibited by the antagonistic activities of other organisms. There fore the presence of staph.aureus in foods must be considered in relation to the amount and types of the accompanying flora.

(Fahim et al., 2015) reported that the incidence of isolated Satph.aureus in the examined samples of street vended meat product sandwiches was recorded in sausage $(55 \%)$ and beef-burger $(40 \%)$ they were nearly similar to the obtained results in this study, while he could isolate the organism from $(45 \%)$ of kofta sandwiches which was higher than that obtained in this study. Also he found that the mean values of Staph.aureus count (cfu/g) in the examined samples of kofta, beef-burger and sausage sandwiches were $8.13 \times 10^{2}, 7.54 \times 10^{2}$ and $1.96 \times 10^{3}$ respectively, they were higher than that obtained in this study, and he 
reported that $52.5 \%$ of the total examined samples fell in the category borderline based on their total Spaph.aureus count $\left(20-\leq 10^{4} \mathrm{cfu} / \mathrm{g}\right)$, it was a worse report than that obtained in this study.

Also higher results were obtained by IbrahimHemmat et al. (2014) who found that the mean values of Staph.aureus count in the examined samples of kofta and sausage sandwiches collected from restaurants were $9.35 \times 10^{2}$ and $2.76 \times 10^{3}$ respectively. While, Ahmed, (1991), Tolba, (1994), and Mohamed, (2000) failed to detect and isolate Staph.aureus from any of the examined samples of heat treated meat products.

In general Staph.aureus isolated from fast foods was more likely comes from food handlers (Baumgartner et al., 2014), moreover (Potter, 2001) reported that total Staph.aureus count can be taken as index of sanitary conditions under which the meat and its products are manufactured and handled.

E.coli used as an indictor microorganism because it provides an estimate of fecal contamination and poor sanitation during processing (Eisel et al., 1997). Its presence in fast foods indicates that the food has been prepared under poor hygienic conditions (KhaterDalia et al., 2013).

From the results illustrated in table (7) it's obvious that the incidence of E.coli isolated from the examined samples were $10 \%, 10 \%, 20 \%$ and $10 \%$ for kofta sandwiches collected from restaurants, street vended burger sandwiches, street vended sausage sandwiches and sausage collected from restaurants respectively, while the organism could not be isolated from street vended kofta sandwiches and beef burger sandwiches collected from restaurants. E.coli was previously isolated from ready to eat meat products by (Fahim et al., 2015) who could isolate the organism from Kofta, beef burger and sausage sandwiches with an incidence of $15 \%, 10 \%$ and $25 \%$ respectively.

Also data obtained in the same table revealed that the isolated serotypes of pathogenic E.coli from the examined samples of kofta sandwiches collected from restaurants was $\mathrm{O}_{127}: \mathrm{H}_{4}(10 \%)$, and the serotype $\mathrm{O}_{26}$ : $\mathrm{H}_{11}(10 \%)$ was isolated from the examined samples of street vended burger sandwiches, while in the examined samples of street vended sausage sandwiches the serotypes $\mathrm{O}_{26}: \mathrm{H}_{11}(10 \%)$ and $\mathrm{O}_{55}: \mathrm{H}_{7}$ $(10 \%)$ were identified, moreover the serotype $\mathrm{O}_{111}: \mathrm{H}_{2}$ could be isolated from sausage sandwiches collected from restaurants with a percentage of $(10 \%)$. In this respect Hassanin et al. (2014) could isolate E.coli $\mathrm{O}_{26}, \mathrm{O}_{111}: \mathrm{H}_{4}$ and $\mathrm{O}_{127}: \mathrm{H}_{6}$ from kofta sandwiches with a percentage of $13.3 \%, 6.7 \%$ and $6.7 \%$ respectively. Also, Fahim at al. (2015) could isolate E.coli $\mathrm{O}_{111}: \mathrm{H}_{4}$ and $\mathrm{O}_{127}: \mathrm{H}_{7}$ from street vended kofta sandwiches with a percentage of $10 \%$ and $5 \%$ respectively and from beef burger sandwiches he could isolate E.coli $\mathrm{O}_{55}: \mathrm{H}_{7}$ and $\mathrm{O}_{119}: \mathrm{H}_{4}$ with a percentage of $5 \%$ for each, while from sausage sandwiches he could isolate E.coli $\mathrm{O}_{26}: \mathrm{H}_{11}, \mathrm{O}_{55}: \mathrm{H}_{7}, \mathrm{O}_{111}: \mathrm{H}_{4}$ and $\mathrm{O}_{119}: \mathrm{H}_{4}$ with a percentage of $5 \%, 5 \% 5 \%$ and $10 \%$ respectively.

In recent years, E.coli has become recognized as a serious food borne pathogen and has been associated with numerous outbreaks of disease in the UK, Japan and USA (Scotter et al., 2000).

Some other genera of the family, Enterobacteiraceae could be isolated as shown in Table (8), that Proteus mirabilis was isolated from street vended burger sandwiches with an prevalence rate $30 \%$, and Klebsiella pmeumoniae was isolated with an prevalence rate $10 \%$ and $20 \%$ from kofta sandwiches collected from restaurants and street vended sausage sandwiches respectively, Also Enterobacter aerogenes was isolated with an prevalence rate $10 \%$ from kofta sandwiches collected from restaurants. These isolated genera of the family Enterobacteriaceae are normal flora of the intestinal tract and are considered opportunistic pathogens.

While Salmonella spp. could not be isolated from any of the examined samples. The results agreed with Khater - Dalia et al. (2013), who reported that no samples tested in their study were found to contain salmonella spp.

\section{CONCLUSION AND RECOMMENDATION}

The results of the present study revealed the occurrence of enteropathogenic E.coli and staph.aureus, also revealed presence of some sandwiches with borderline quality due to their APC, in addition to the contamination with Enterococci. Occurrence of these pathogens in fully ready-to-eat sandwiches render the quality of the foods examined inadequate. Relevant authorities should educate food handlers on good personal hygiene and good manufacturing practices, which are sure ways of reducing the likelihood of the foods serving as vehicles for food-borne illnesses.

The above mentioned hazards can be minimized to a great extent simply by monitoring the microbiological quality of food and creating awareness among the people about the fundamental principles of sanitation and hygienic quality of food.

Although governments throughout the world are attempting to improve the safety of food supply, the occurrence of food borne disease remain a significant health issue in both developed and developing countries (WHO, 2011). 


\section{REFERENCE}

Ahmed, I.M. (1991): Hygienic quality of marketed ready to eat meat. M.V.Sc. Thesis, Meat Hygiene, Fac. of Vet. Med. Zagazig Univ.

Alzbeta, M. and Lubomir, V. (2012): staphylococcus aureus: Characterization and quantitative growth description in milk and artisanal raw milk cheese production. Chapter 4. INTECHc Medcvedova and valik, licensee in tech. this is as open access chapter distributed under the terms of the creative commons attribution license.

APHA (American public Health Association) (1992): Compendium of methods for the microbiological examination of foods. $3^{\text {rd }} \mathrm{Ed}$. Speck, H.L. (ed.). Washinton D. C. APHA.

APHA (American Public Health Association) (2001): Compendium of methods for the microbiological examination of food. $4^{\text {th }} \mathrm{Ed}$ Washington D., USA.

Baumgartner, A.; Niederhauser, I. and Johler, S. (2014): Virulence and resistance gene profiles of staphylococcus aureus starains isolated from ready - to-eat foods $\mathrm{J}$. food protect 7 : 1232-1236.

CFS, (Center for food safety) (2014): Microbiological Guidelines for ready to eat food. risk Assessment section, food and environmental Hygiene Department 43/F, Queensway Government offices, 66 Queensway, Hong kong.

Cheesbrough, M. (1984): Microbiological examination of specimens and biochemical testing of microorganism in Medical laboratory manual for tropical countries. $1^{\text {st }}$ edition. Volum2. Tropical Health Technology, Butterworth Heinemann Ltd. Printed in Great Britain At University press, Cambridge. 26-39, 57-69s.

Cowan, S.T. and Steel, K.J. (1974): Manual for identification of medical bacteria. Cambridge Univ. Press, London, New York, Malburne.

Deibel, R.H. and Hartman, P.A. (1982): The Enterocci In: Compendium of methods for the microbiological examination of foods. $2^{\text {nd }} \mathrm{Ed}$., Speck, M.L. (Ed.), APHA., Inc.

Eisel W.G.; Lintion, R.H. and Muriana, P.M. (1997): A survey of microbial levels for incoming raw beef, environmental sources and ground beef in a red meat processing plant. J. Food microbial. 14: 273-282.

Fahim, A-El.Sh.; Mohamed, A.H. El-Sh. and Wafaa, M.A-El.A. (2015): Bacteriological assessment of street vended meat products sandwiches in kalyobia Governorate. B. V.M. J. 2: 58-66.

FAO (2007): Food and Agriculture Organization of the United Nation, Manual of food Quality control. United Nation, Rome.
FDA (Food and Drug Administration) (2009): Escherichia coli. Food-borne pathogenic Microorganisms and Natural Toxins Handbook. http:/vm.cfsan.fda.gov.

FDA (Food and Drug Administration) (2001): Staphylococcus aureus. Bacteriological analytical manual $8^{\text {th }}$ Ed. Chapter 12 Gatithers burg, aP. 562.

Foulquie Moreno, M.; Sarantinopoulos, P.; Tsakalidou, E. and De vuyst, L. (2006): the role and application of enterocci isolated in food and health. Int. J. Food Microbiol. 106: $1-24$.

Giraffa, G. (2002): Enterocci from foods. FEMS Micobiol Rev. 26: 163-171.

Hassanin, F.S.; Reham, A.A.; Shawky, N.A. and Gomaa, W.M. (2014): Incidence of Escherichia coli and slamonella in ready to eat foods. Benha Veterinary Medical journal 27, (1): 84-91.

Hefnawy, Y.A. and Youssef, H.H. (1984): Microbiological evaluation of some selected spices. Assiut Vet. Med. J. 13: 145-149.

HPA (Health protection Agency) (2007): Standard methods for food products. Detection of Salmonella spp. Standard Methods: F13, Issue 3. HPA, London Available at:/ http:/www.hpastandar dmethods. org. uk/documents/food/ pdf/F13.Pdf S.

Ibrahim-Ghada, M.M. (2001): Ready to eat sandwiches as a source of potential pathogen in Assiut City. M.V. Sc., thesis (Meat Hygiene), Fac. Vet. Med. Assiut Univ.

Ibrahim-hemmat, M.; Reham, A.A. and Sobieh, A.S. (2014): Bacteriological evaluation of fast foods at restaurants level in Cairo Governorate. Benha Veterinary Medical Journal, 26 (1): 34-42.

ICMSF (international commission of microbiological specification for food) (1996):

Microorganisms in Food I-Their significance and methods of enumeration $3^{\text {rd }}$ Ed. Univ. of Tornoto, Canada.

Kawo, A.H. and Abduimumn, F.N. (2009): Microbiology quality of prepackaged sweets sold in metropolitan kano, Bayero J.Sci. 2(1): 154-159.

Khater-Dalia, F.; Heikal, G.E.; Shehata, A.A. and EHofy, F.I. (2013): The microbiological Assessment of ready-to-Eat food (liver and kofta sandwiches) in Tanta City, Egypt, Benha Vet. Med. J. 25 (2): 187-197.

Kok, T.; Worswich, D. and Gowas, E. (1996): Some serological techniques for microbial and viral infections. In Practical Medical Microbiology (Collee. J.; Fraser. A.; Marmion, B. and Simmons, A. eds.), $14^{\text {th }}$ ed. Edinburgh, Churchill Livingstone. UK.

Maturin, L.J. and peeler, J.T. (1998): Aerobic plate count. Ch. 3. In food and Drug administration. 
Bacteriological Analytical Manual, $8^{\text {th }}$ Ed. (revision A), (CD-ROM) version). R.L Merker (Ed.) AOAC International, Gaithersburg, M.D. Mohamed, E.N. (2000): Quality investigation into beef frankfurter produced in Egypt. M.V. Sc. Thesis, Fa. Vet. Med. Cairo Univ.

Morrison, D.; Woodford, N. and Gowans, E. (1997): Some serological techniques for microbial and viral infections. In Practical Medical Microbiology (Collee, J., Fraser, A.; Marmion, B. and Simmons, A.eds.), $14^{\text {th }}$ ed., Edinburgh, Churchill Livingstone, UK.

Murray, PR. (2003): Manual of clinical Microbiology. 8th edition ASM Press. 29: 4144.

Normanno, G.; Corrente, M.; La salandra, G.; Dambrosio, A.; Quaglia, N.C.; Parisi, A.; Greco, G.; Bellacicco, A.L.; Virgilio, S. And Celano, G.V. (2007): Methicillin-Resitance staphytococcus aureus (MRSA) in foods of animal origin product in Italy international $\mathrm{J}$. of food microbiology. 117: 219-222.

Potter, N.N. (2001): Street vended food in developing world: hazard analysis indian J. Microbiol. 51 (1): 100-106.
Roberts, D. (1990): Sources of infection food. Lancet British Edition: 336: 859-861.

Scotter, S.; Aldridge, M. and Capps, K. (2000): Validation of method for the detection of E.coli $\mathrm{O}_{157}: \mathrm{H}_{7}$ in foods. Food control. 11: 8595.

Sharmila, R. (2011): Street vended food in developing world hazard anaylsis, Indian $\mathrm{J}$. Microbiol 51 (1): 100-106.

S.P.S.S "Statistical package for social sciences" (2007): S.P.S.S. version 16, Inc., Chicago, IL.

Stiles, M.E. and Holzapfel, W.H. (1997): Lactic acid bacteria of foods and their current taxonomy. Int. J. Food Microbiol., 36: 1-29.

Syne, S.M.; Ramsubhag, A. and Adesiyun, A.A. (2013): Microbiological hazard analysis of ready to eat meats processed at food plant in Trinidad, west indies, infection Ecology and epidemiology, 3, view at Google scholar.

Tolba, K.S. (1994): Microflora in locally processed frozen meat. Vet. Med. j. Giza, 42 (2): 99.

WHO (2011): Knowledge = prevenation. The five keys to saferfood 18th April 2011. Food safety and zoonoses. http://www.who. Imt/ foodsafety/en/.

\section{دور الوجبات السريعة في نقل بعض المخاطر البكتيرية للمستهلك \\ لبني محمد إبراهيم ، أزهار محد حسن \\ E-mail: ghada02468@yahoo.com \\ Assiut University web-site: www.aun.edu.eg}

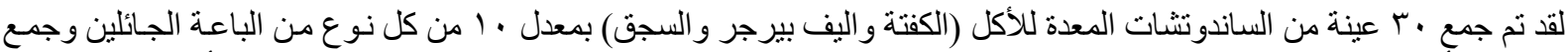

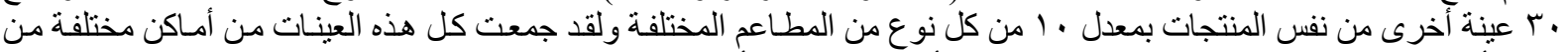

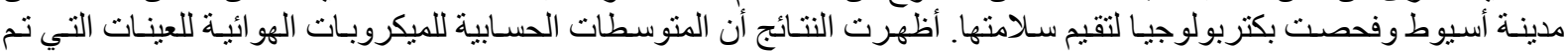

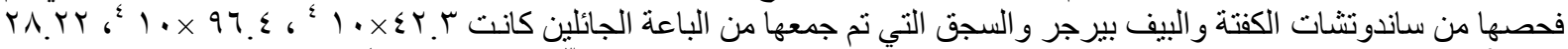

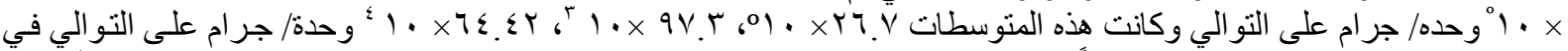

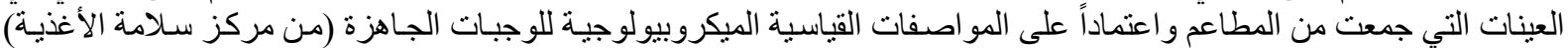

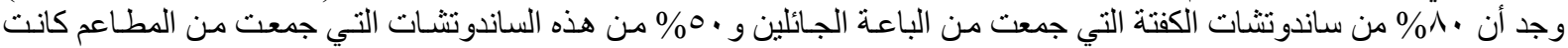

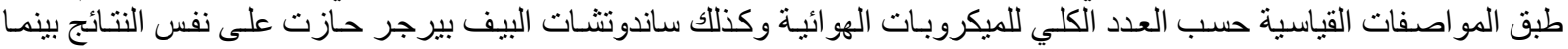

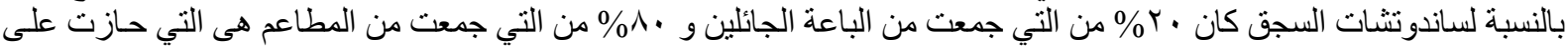

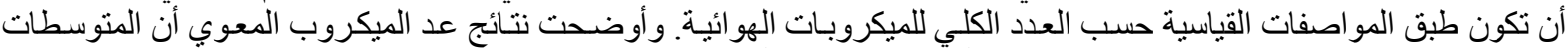

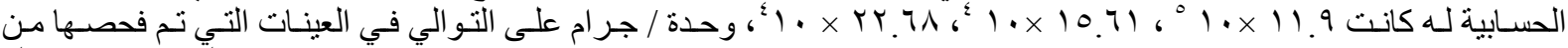

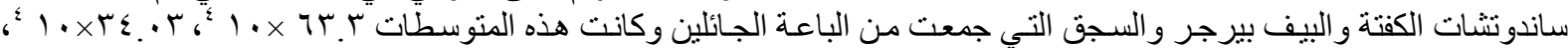

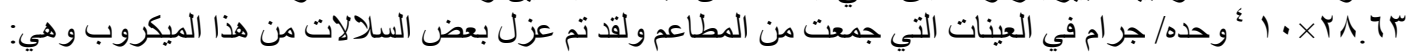
Ent.columbae, Ent.cecorum, Ent. Mundtii, Ent. Hirea and Ent.Facium.

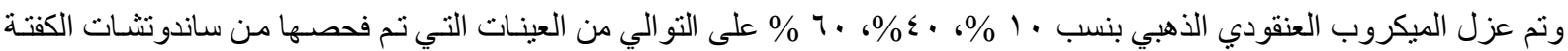

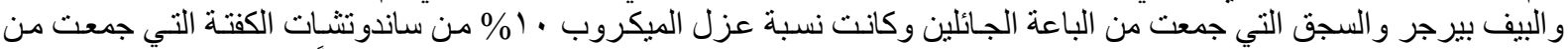

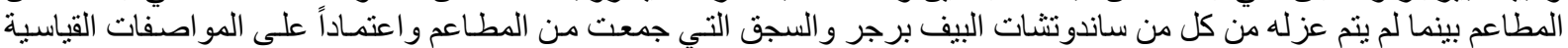

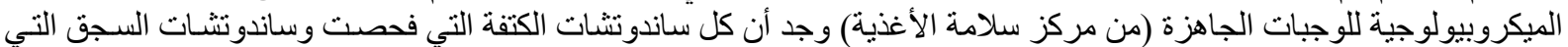

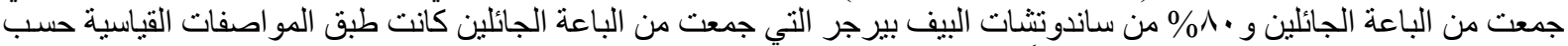

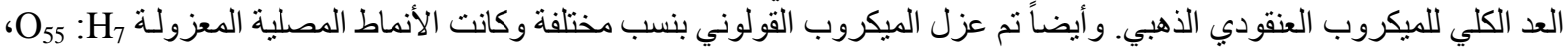
$\mathrm{O}_{127}: \mathrm{H}_{4}$ ، $\mathrm{O}_{26}: \mathrm{H}_{11}$ 'O $\mathrm{O}_{111}: \mathrm{H}_{2}$ 